\title{
Pemberdayaan Kelompok Tenun Nari-Nari Melalui Pewarnaan Benang Menggunakan Ekstrak Kayu Kuning Dan Kayu Mahoni
}

\author{
Agrippina Wiraningtyas ${ }^{1}$, Ruslan $^{2 *}$, Ahmad Sandi ${ }^{3}$, Muh. Nasir ${ }^{4}$ \\ Sekolah Tinggi Keguruan dan Ilmu Pendidikan (STKIP BIMA) \\ agriwiraningtyas@gmail.com, ruslanabinada@gmail.com*,ahmadsandi_73@gmail.com, \\ muh_nasir_bio@stkip.ac.id
}

\begin{abstract}
The "Nari-Nari" Weaving Village in Rabadompu Timur Village, Bima City, is a community group engaged in the weaving industry which has been carried on for generations. During this time, Bima woven fabric products use yarn raw material that has been colored using synthetic dyes. Yarn with synthetic dyes has a more diverse color, the fabric coloring process is easier and the cost is cheap, but synthetic dyes are carcinogenic and harmful to the environment. The solution to the problems faced by using natural dyes obtained from plants. This activity aims to train the NariNari weaving group in yarn coloring using natural dyes. The method used is training through several stages of the activity namely the stage of socialization of activities; the training stage of yarn dyeing and woven fabric production. The dyes used are yellow wood extract and mahogany wood. The results obtained in this activity are the colored yarn has a different color based on the extract of the dye and fixation material. In yellow wood obtained with a maroon red color on alum, black on tunjung and reddish beige on lime. In mahogany wood is obtained beige on alum, black gray on tunjung and beige on lime.
\end{abstract}

Keywords: Weaving Village of Nari-Nari; Bima Woven Fabrics; Natural dyes; yellow wood extract; mahogany.

\begin{abstract}
Abstrak
Kampung Tenun "Nari-Nari” di Kelurahan Rabadompu Timur Kota Bima merupakan kelompok masyarakat yang bergerak dibidang industri kerajinan tenun yang telah dilakukan secara turun temurun. Selama ini, produk kain tenun Bima menggunakan bahan baku benang yang sudah diwarnai menggunakan pewarna sintetis. Benang dengan pewarna sintetik memiliki warna yang lebih beragam, tidak mudah luntur, mudah diproduksi, proses pewarnaan kain lebih mudah dan biayanya murah, namun pewarna sintetik bersifat karsinogenik dan berbahaya bagi lingkungan. Solusi dari permasalahan yang dihadapi dengan menggunakan pewarna alami yang diperoleh dari tanaman. Kegiatan ini bertujuan untuk melatih kelompok tenun Nari-Nari dalam pewarnaan benang menggunakan zat warna alam. Metode yang digunakan yaitu pelatihan melalui beberapa tahapan kegiatan yaitu tahap sosialisasi kegiatan; tahap pelatihan pewarnaan benang dan produksi kain tenun. Zat warna yang digunakan yaitu ekstrak kayu kuning dan kayu mahoni. Hasil yang diperoleh pada kegiatan ini adalah benang hasil pewarnaan memiliki warna yang berbeda berdasarkan ekstrak zat warna dan bahan fiksasi. Pada kayu kuning diperoleh benang dengan
\end{abstract}


warna merah maron pada tawas, hitam pada tunjung dan krem kemerahan pada kapur. Pada kayu mahoni diperoleh warna krem pada tawas, abu-abu kehitaman pada tunjung dan krem pada kapur.

Kata Kunci: Kampung tenun nari-nari; Kain tenun bima; Pewarna alam; Ekstrak kayu kuning; Kayu mahoni.

\section{A. PENDAHULUAN}

Kain tenun dari daerah Bima diberi nama songket Bima atau kain tenun Mbojo adalah produk kerajinan budaya masyarakat Bima yang pembuatannya telah ada secara turun temurun sejak abad ke-15. Munculnya kain tenun Bima tidak terlepas dari sejarah perkembangan Islam. Kain tenun Bima menjadi semacam pakaian wajib yang harus dikenakan perempuan muslim saat keluar rumah. Peraturan adat ini akhirnya menjadikan kain tenun sebagai identitas masyarakat Mbojo. Kain tenun Bima merupakan salah satu produk seni kerajinan masyarakat Mbojo sampai saat ini masih banyak digunakan untuk keperluan upacara adat. Oleh sebab itu, ragam hiasnya mempunyai makna dan nilai filosofis tersendiri bagi masyarakat Mbojo. Hal itu membedakan motif tenun Bima dengan motif tenun beserta nilai filosofis dari daerah lain (Suwondo,1978). Perkembangan makna simbol dan motif kain tenun Bima semakin meningkat dengan perkembangan zaman. Proses pembuatan motif kain tenun Bima hampir sama dengan proses pembuatan motif kain tenun daerah lain. Tetapi kain tenun Bima mempunyai ciri khas yang membedakan dengan motif tenun daerah lain. Dalam memilih simbol dan gambar untuk dijadikan motif tenun kain Bima harus berpedoman pada nilai dan norma agama (Mubin, 2016).

Produksi kain tenun Bima masih menggunakan peralatan yang sederhana yaitu menggunakan alat tenun gedogan sehingga ukuran yang diperoleh untuk satu kain sekitar 2 x 0,6 m. Kain tenun Bima memiliki beragam jenis seperti tenun mesrai, tenun nggoli, tenun renda dan tenun galendo. Dari kain tenun tersebut dapat dijadikan sarung, baju, syal, selendang, sambolo, weri, dan jenis pakaian adat lainnya. Pada awalnya, bahan baku pembuatan kain tenun digunakan kapas kemudian dipintal sendiri oleh masyarakat, namun saat ini semakin berkurang bahkan sekarang tidak ada lagi yang menggunakan bahan tersebut, karena sudah banyak bahan baku benang yang menggunakan zat warna sintetis. Dalam pembuatan kain tenun Bima, ada beberapa tahapan yang harus dilakukan sebelum dilakukan proses menenun. Beberapa tahapan yaitu proses 1) pemintalan benang: moro kafa, ngane kafa, cubu kafa dei cau, luru kafa, nggulu kafa; 2) proses persiapan alat dan 3) menenun (Wijaya, dkk. 2012).

Permasalahan yang dihadapi dalam pengembangan kampung tenun "Nari-Nari" di Kelurahan Rabadompu Barat Kota Bima untuk meningkatkan kualitas produksi kain tenun Bima adalah bahan baku benang yang digunakan dalam pembuatan kain tenun Bima berupa benang sudah diwarnai menggunakan pewarna sintetik. Pewarna sintetik memiliki warna yang lebih beragam, tidak mudah luntur, mudah diproduksi, proses pewarnaan kain lebih mudah dan biayanya murah. Namun, pewarna sintetik bersifat karsinogenik dan berbahaya bagi lingkungan sehingga mengurangi nilai artistik dan sisi eksotiknya. Pewarna sintetik mengandung senyawa yang tidak mudah 
terdegradasi oleh lingkungan. Limbah yang dihasilkan dari proses produksi industri tekstil juga mengandung logam berat seperti kromium $(\mathrm{Cr})$, timah $(\mathrm{Sn})$, tembaga $(\mathrm{Cu})$ dan seng (Zn) (Inayat, et al. 2010).

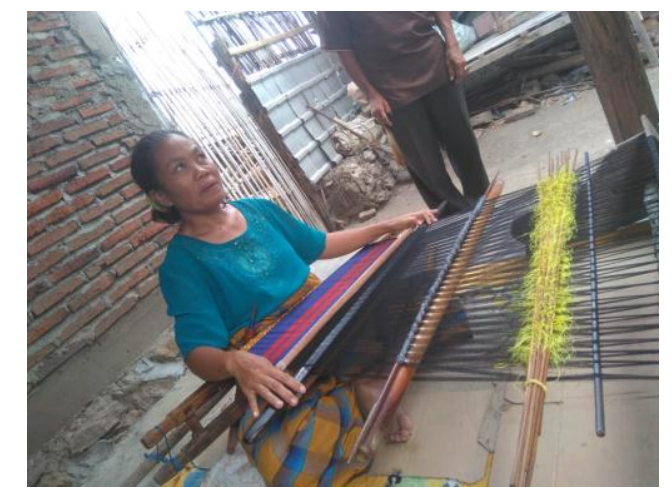

Gambar 1. Proses Pembuatan Kain Tenun Bima

Solusi dari permasalahan yang dihadapi dalam pengembangan kampung tenun "NariNari" di Kelurahan Rabadompu Barat Kota Bima adalah penggunaan zat warna alam pada pewarnaan benang. Pewarnaan benang dengan pewarna alami banyak memberikan manfaat bagi keberlangsungan alam dan generasi mendatang. Sejalan dengan konsep pembangunan berkelanjutan dan pemanfaatan produk ramah lingkungan, pemanfaatan sumber-sumber pewarna alami yang dulu sempat ditinggalkan kembali dilakukan. Bahkan di beberapa negara maju seperti Jerman dan Belanda telah merealisasikan pelarangan penggunaan zat pewarna sintetik sejak tahun 1996. Oleh karena itu, saat ini sudah bermunculan produk-produk tekstil yang menggunakan bahan pewarna alami seperti kain tenun. Penggunaan pewarna alam pada benang merupakan salah satu tahapan pada pembuatan kain tenun tradisonal Bima secara turun temurun. Pewarna alam memiliki banyak kelebihan diantaranya warna yang dihasilkan lebih natural, sejuk, unik dan indah sesuai karakteristik warna alam, limbah yang dihasilkan lebih ramah lingkungan (biodegradable), ketersediaan bahan baku melimpah (renewable). Kain tenun yang menggunakan bahan pewarna alami akan tebukti memiliki nilai artistik dan sisi eksotiknya tersendiri sehingga berpotensi sebagai komoditas ekspor serta harga yang tinggi. Oleh karena itu perlu dilakukan penggunaan zat warna alam pada pewarnaan benang dalam proses pembuatan kain tenun Bima untuk menghasilkan produk berkualitas tinggi sehingga menjadi produk komoditas unggulan asli Indonesia.

Zat warna alami adalah zat warna yang diperoleh dari bahan alam seperti dari tanaman, bakteri, jamur dan alga baik mikro maupun makroalga. Secara tradisional, zat warna alami diperoleh dengan ekstraksi atau perebusan tanaman di sekitarnya. Bagianbagian tanaman yang dapat digunakan untuk zat warna alami adalah kulit, ranting, daun, akar, bunga, biji atau getah. Zat warna alami mempunyai efek warna yang indah dan khas yang sulit ditiru zat warna sintetik, sehingga masih banyak kalangan yang menyukai dan merupakan pendukung produk-produk eksklusif dan bernilai seni tinggi (Lusiana, et al. 2005). Setiap tanaman dapat merupakan sumber zat warna alami, karena mengandung pigmen alam. potensi ini ditentukan oleh intensitas warna yang dihasilkan dan sangat tergantung pada jenis coloring matter yang ada. Coloring matter adalah substansi yang menentukan arah warna zat warna alam, merupakan senyawa organik yang mengandung lebih dari satu jenis coloring matter. Berdasarkan jenis coloring matter, zat warna alami dibagi menjadi 4 golongan yaitu zat warna mordan, zat warna direk, zat warna asam/basa dan zat warna bejana (Paryanto, dkk. 2015). Sumber pewarna alami yang biasa digunakan untuk pewarna seperti batang pisang berwarna cokelat; akar mengkudu berwarna mera, kuning dan cokelat; daun tarum berwarna biru; daun sirih 
berwarna cokelat; buah pinang berwarna merah tua; daun mangga berwarna hijau; kulit mahoni berwarna cokelat; daun jati berwarna cokelat muda; buah nenas berwarna merah; rimpang kunyit berwarna kunyit; rumput laut berwarna biru, cokelat. Metode ekstraksi yang biasa digunakan untuk mendapatkan pigmen dari tanaman tergantung pada sifat pigmen yaitu menggunakan pelarut air. Metode ini sangat mudah dan setiap orang dapat melakukannya. Selain itu pelarut yang digunakan dalam metode ini murah dan mudah didapatkan. Namun kelemahan dari ekstraksi menggunakan pelarut air adalah ekstrak yang diperoleh mudah berjamur apabila kedalam ekstrak tidak menggunakan bahan pengawet dan penyimpanan yang benar. Apabila pewarna alam akan disimpan pasta, pelarut harus harus diuapkan terlebih dahulu menggunakan teknik tertentu. Salah satu teknik penguapan yang dapat digunakan adalah dengan pengovenan. Meskipun keberadaan pewarna alam sangat melimpah, tetapi pewarna alam memiliki beberapa kelemahan seperti mudah memudar, warna kurang seragam, dan waktu proses produksi untuk menghasilkan pewarna lebih lama. Selain itu diperlukan metode tertentu untuk memperoleh pewarna alam. mengingat bahwa kain yang diwarnai dengan pewarna alam akan menghasilkan warna yang lebih eksotis, elegan dan juga ramah lingkungan, maka diperlukan cara untuk mempopulerkan pewarna alam pada usaha kecil dan menengah khususnya pada kain tenun Bima (Indrianingsih, dkk. 2013).

Material benang pada umumnya sulit berikatan dengan zat warna. Oleh karena itu, sebelum dilakukan pewarnaan pada benang dilakukan proses mordanting untuk menghilangkan pengotor yang menempel pada benang. Untuk memperoleh zat warna yang mempunyai ketahanan luntur baik maka perlu dilakukan proses fiksasi zat warna. Fiksasi dapat berfungsi memperkuat warna dan merubah zat warna alam sesuai dengan jenis logam yang mengikatnya serta mengunci zat warna yang telah masuk kedalam serat. Bahan yang biasa digunakan untuk fiksasi adalah tawas $\left[\mathrm{K}_{2} \mathrm{SO}_{4} \cdot \mathrm{Al}_{2}\right.$ $\left.\left(\mathrm{SO}_{4}\right)_{3} .24 \mathrm{H}_{2} \mathrm{O}\right]$, kapur $\left(\mathrm{CaCO}_{3}\right)$ dan tunjung (FeSO 4$)$ (Hartanto, 2003).

\section{B. PELAKSAAAN DAN METODE}

Metode yang digunakan dalam pelaksanaan kegiatan pengabdian Program Pengembangan Produk Unggulan Daerah dengan judul pengembangan kampung tenun "Nari-Nari" di Kelurahan Rabadompu Timur Kota Bima dilakukan beberapa tahapan diantaranya:

Tahapan persiapan meliputi penyiapan proses administrasi, penyusunan materi, instrument dan langkah kegiatan. Sosialisasi kegiatan pelatihan kepada kelompok masyarakat mitra untuk menginformasikan rencana kegiatan yang akan dilakukan.

\section{Pembuatan Zat Warna Alam}

Alat yang diperlukan: panci, kompor, saringan, bak perendaman, dan bak cuci. Sedangkan bahan yang digunakan: benang tenun, air, kayu kuning dan kayu mahoni.

\section{Pembuatan ekstrak zat warna}

Kayu kuning direbus dengan air dengan perbandingan 1:10 (b/v) selama 1 jam kemudian disaring. Filtrat yang diperoleh selanjutnya diuapkan hingga diperoleh setengahnya dan didinginkan. Ekstrak yang diperoleh digunakan sebagai zat warna pada proses pewarnaan benang.

\section{Mordanting Benang}

Sebelum dilakukan proses pewarnaan, benang terlebih dahulu dimordanting menggunakan larutan tawas pada suhu $60{ }^{\circ} \mathrm{C}$ 
selama 1 jam, selanjutnya dijemur selama 30 menit.

\section{Pewarnaan Benang}

Benang yang sudah dimordanting selanjutnya dicelupkan dalam zat warna selama 24 jam kemudian dijemur selama 30 menit. Selanjutnya benang dicelup kembali selama 30 menit sampai dua kali pengulangan dan dijemur sampai kering.

\section{Proses Fiksasi}

Benang yang sudah diwarnai selanjutnya difiksasi masing-masing dengan tunjung, tawas dan kapur tohor melalui perendaman selama 30 menit sampai semua benang terendam dan kemudian dijemur sampai kering.

\section{Finishing}

Benang hasil fiksasi selanjutnya dicuci menggunakan air dan dibilas hingga bersih dan kemudian dijemur sampai kering. Benang yang sudah kering selanjutnya dikemas dalam kemasan plastik sesuai dengan sumber zat warna alam dan bahan fiksasi.

\section{HASIL DAN PEMBAHASAN}

\section{Sosialisasi Kegiatan PPPUD}

Kegiatan Pengabdian Kepada

Masyarakat Program Pengembangan Produk Unggulan Daerah (PPPUD) pada tahun ke-1 bertujuan untuk mengembangkan kelompok tenun di Kelurahan Rabadompu Timur Kota Bima dalam penggunaan zat warna alam dalam pewarnaan benang tenun. Kegiatan tersebut diawali dengan sosialisasi kegiatan PPPUD pada mitra pengguna. Pada kegiatan tersebut dilakukan sosialisasi dan diskusi bersama kelompok masyarakat mitra tentang program yang akan dilaksanakan pada kegiatan pengabdian kepada masyarakat.

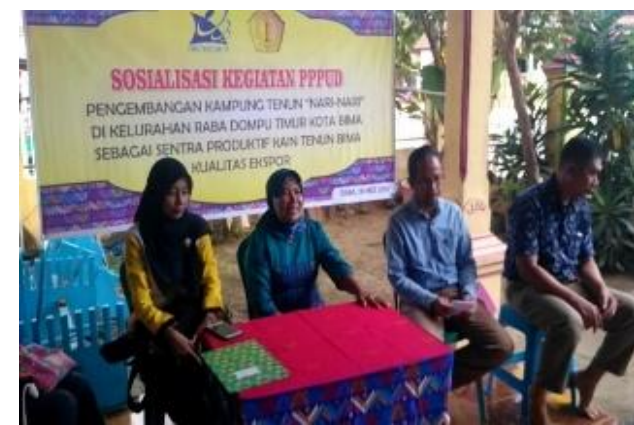

Gambar 2. Sosialisasi Kegiatan PPPUD dengan Mitra

Selama pelaksanaan kegiatan, kelompok mitra ikut serta berpartisipasi secara aktif. Beberapa hasil kesepakatan pada kegiatan sosialisasi diantaranya kelompok mitra menyiapkan tempat kegiatan; kelompok mitra memiliki kesadaran untuk meningkatkan perekonomian keluarga; kelompok mitra mampu mencari solusi guna memecahkan masalahnya; anggota Koperasi Wanita Nari-Nari dibagi dalam beberapa kelompok sesuai dengan jenis kegiatan; kelompok yang dibagikan yaitu kelompok pewarnaan benang, kelompok pengrajin tenun dan kelompok produk kreatif.

\section{Pewarnaan Benang Tenun}

Pada pewarnaan benang tenun dilakukan dengan menggunakan zat warna alam berupa kulit kayu kuning dan kayu mahoni.
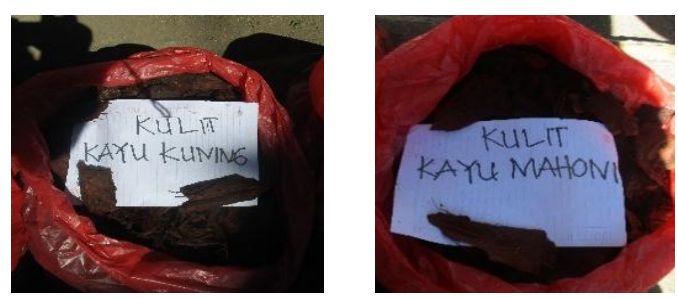

Gambar 3. Bahan Baku Pewarna Alam

Kulit kayu kuning dan kayu mahoni masing-masing dicuci sampai bersih untuk menghilangkan kotoran yang menempel, selanjutnya dilakukan proses ekstraksi dengan memasukkan kulit kayu kuning dan 
kayu mahoni masing-masing ke dalam panci dan ditambahkan air dengan perbandingan 1:10 (b/v). campuran dipanaskan selama 1 jam dan didinginkan. Campuran tersebut selanjutnya disaring dan filtrat yang diperoleh selanjutnya dipekatkan dengan cara menguapkan pelarut sehingga volume ekstrak menjadi setengahnya. Esktrak yang diperoleh selanjutnya didinginkan dan siap digunakan dalam pewarnaan benang. Zat warna dari kulit kayu kuning dihasilkan ekstrak berwarna merah cerah sedangkan pada kayu mahoni dihasilkan ekstrak berwarna merah kecoklatan.

Sebelum dilakukan proses pewarnaan, terlebih dahulu benang dimordanting menggunakan tawas. Benang putih dimasukkan kedalam panci yang telah diisi dengan larutan tawas dan dipanaskan selama 30 menit selanjutnya ditiriskan sampai air pada benang tidak menetes lagi.. Mordanting dilakukan untuk menghilangkan kotoran berupa lemak dan pengotor lainnya yang tidak larut dalam air.

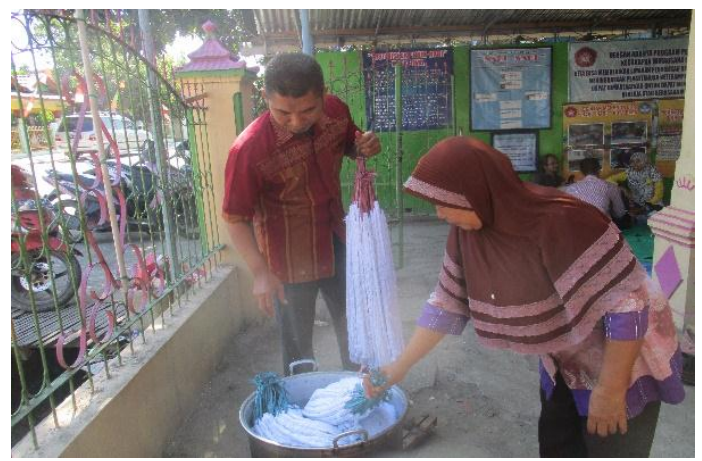

Gambar 4. Proses Mordanting

Benang yang sudah dimordanting selanjutnya dimasukkan kedalam wadah yang telah diisi dengan ekstrak kulit kayu kuning dan kulit kayu mahoni. Proses pewarnaan benang seperti pada gambar 5 berikut.
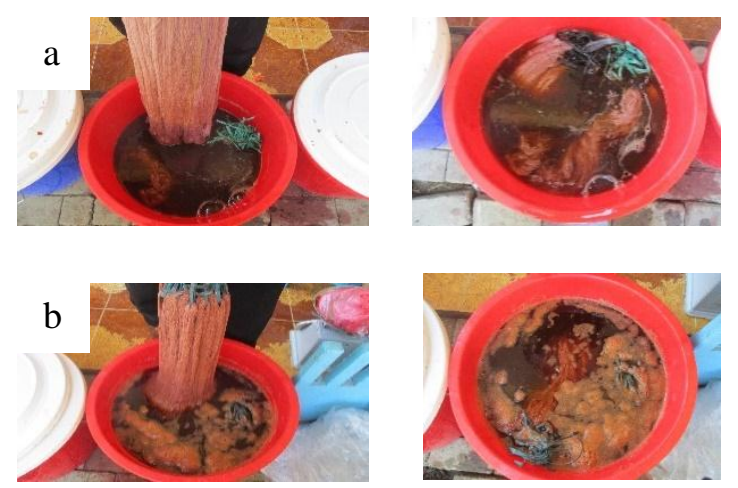

Gambar 5. Pewarnaan benang pada ekstrak a) kayu kuning dan b) kayu mahoni

Proses pewarnaan dilakukan selama 24 jam selanjutnya ditiriskan untuk mengurangi kadar air. Kemudian dicelupkan lagi selama 30 menit sebanyak 2 kali. Hal ini dilakukan untuk mendapatkan warna yang homogen pada permukaan benang.

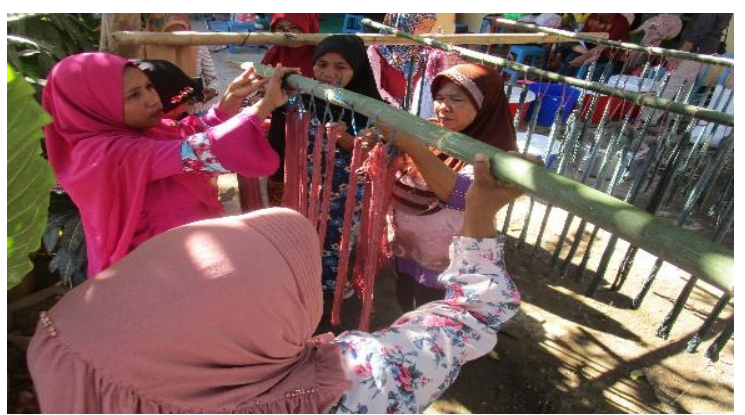

Gambar 6. Proses penjemuran benang

Warna pada benang akan mudah luntur apabila dicuci dengan air. Maka proses selanjutnya yaitu melakukan pengikatan zat warna pada benang yang disebut dengan proses fiksasi. Bahan yang biasa digunakan pada proses fiksasi adalah tawas, tunjung dan kapur. Dengan proses fiksasi dapat meningkatkan kualitas zat warna pada benang dan warna yang dihasilkan akan bervariasi tergantung pada zat pengikatnya meskipun dari sumber zat warna yang sama.

Produk benang hasil pewarnaan menggunakan zat warna dari kulit kayu kuning seperti ditunjukkan pada gambar 7 berikut: 

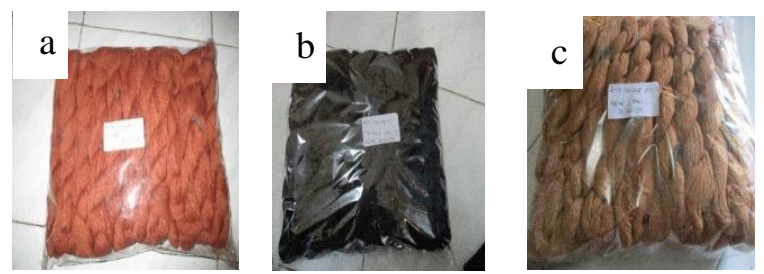

Gambar 7. Benang hasil pewarnaan dari ekstrak kulit kayu kuning pada fiksasi a) tawas; b) tunjung dan c) kapur

Berdasarkan hasil tersebut, produk benang yang dicelupkan pada zat warna dari kulit kayu kuning pada awalnya menghasilkan warna merah maron. Namun setelah difiksasi mengalami perubahan warna yaitu menjadi merah cerah pada fiksasi tawas, hitam pada fiksasi tunjung dan menjadi krem pada fiksasi kapur. Sedangkan produk hasil pewarnaan benang menggunakan zat warna dari kulit kayu mahoni, seperti ditunjukkan pad gambar 8 .
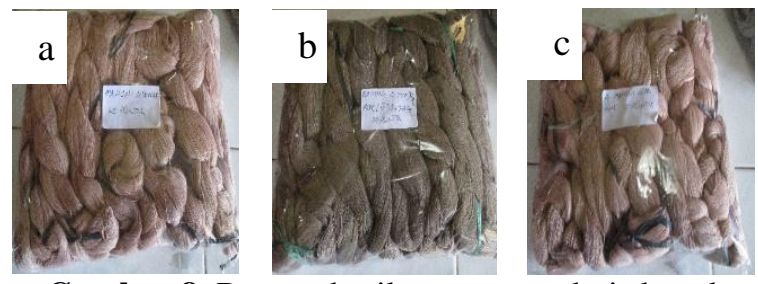

Gambar 8. Benang hasil pewarnaan dari ekstrak kulit kayu mahoni pada fiksasi a) tawas; b) tunjung dan c) kapur

Produk benang yang dicelupkan pada zat warna dari kulit kayu mahoni pada awalnya menghasilkan warna merah maron. Namun setelah difiksasi mengalami perubahan warna yaitu menjadi krem pada fiksasi tawas, abuabu kehitaman pada fiksasi tunjung dan menjadi krem pada fiksasi kapur.

\section{Simpulan}

\section{PENUTUP}

Pelatihan pewarnaan benang dikampung tenun Nari-Nari dapat meningkatkan pengetahuan masyarakat tentang pembuatan dan pemanfaatan zat warna dalam pewarnaan benang. Zat warna yang digunakan pada kegiatan ini diekstrak dari kulit kayu kuning dan kayu mahoni. Produk benang yang dihasilkan pada pewarnaan menggunakan ekstrak kulit kayu kuning adalah benang dengan variasi warna merah cerah, hitam dan krem. Sedangkan pada pewarnaan menggunakan ekstrak kulit kayu mahoni diperoleh benang dengan variasi warna krem dan abu-abu kehitaman.

\section{Saran}

Perlu dilakukan ekstraksi lebih lanjut pada bahan alam lainnya untuk mendapatkan warna yang lebih kontras dan bervariasi.

\section{Ucapan Terima Kasih}

Penulis mengucapkan terimakasih kepada Direktorat Riset dan Pengabdian kepada Masyarakat Direktorat Jenderal Penguatan Riset dan Pengembangan Kementerian Riset, Teknologi dan Pendidikan Tinggi Republik Indonesia yang telah mendanai Pengabdian pada Masyarakat ini melalui skim PPPUD tahun 2019.

\section{E. DAFTAR PUSTAKA}

Hartanto, N.S., Watanabe, S., 2003, Teknologi Tekstil, Jakarta, Pradnya Paramita.

Inayat, A., Khan, S.R., Waheed, A., Deeba, F. 2010. Application of Ecofriendly Natural Dyes on Leather using differen Mordants. Proc. Pakistan Acad. Sci. 47 (3); 131-135.

Indrianingsih, A.W., Darsih, C., Maryana, R. 2013. Pewarna Alam dari Ekstrak Tanaman dan Aplikasinya di Usaha Kecil Menengah Tekstil Indonesia. Prosiding Seminar Nasional Kimia dan Pendidikan Kimia V. PKIM FKIP UNS. 682-691. 
Lusiana, M., Livia, M., Maria, P., Fransisca, L. 2005. Elevation of The Clastogenicity and Anticlastogenicity of The Carotenoid Bixin in Human Lymphocyte Cultures. Mutation Research. 585; 114.

Mubin, I. 2016. Makna Simbol atau Motif kain Tenun Khas Masyarakat Daerah Bima di Kelurahan Raba Dompu Kota Bima Provinsi Nusa Tenggara Barat. Historis. 1 1, 21-24.

Paryanto, Kridyantoro, R., Prabowo, Y.S. 2015. Pembuatan Zat Warna Alami berbentuk Bubuk dari Biji Kesumba. EKUILIBRIUM. 14 1, 13-16.

Suwondo, B. 1978. Adat Istiadat Daerah Nusa Tenggara Barat. Proyek Penelitian dan Pencatatan Kebudayaan Daerah, Depdikbud. Balai Pustaka. Jakarta. 77.

Wijaya, S.I. Ardana, I.G.N.S. Mursal. 2012. Kerajinan Tenun Songket Bima di Lingkungan Nggaro Kumbe Kelurahan Rabadompu Timur Kecamatan Raba Kota Bima Provinsi NTB. Jurusan Pendidikan Seni Rupa. Universitas Pendidikan Ganesha. Singaraja.

Wiraningtyas, A. 2019. Ekstraksi Zat Warna Dari Rumput Laut Sargassum Sp. Jurnal Redoks: Jurnal Pendidikan Kimia Dan Ilmu Kimia, 2 1, 1-10. 